\title{
NOTES
}

\section{APPRAISAL OF CORPORATE DISSENTERS' SHARES: APPORTIONING THE PROCEEDING'S FINANCIAL BURDENS}

WeEN the dynamics of modern enterprise lead to intracorporate conflict, appraisal statutes ${ }^{1}$ are an important vehicle of compromise. Expansion or rehabilitation of the corporation may call for far-reaching structural readjustments. ${ }^{2}$ But the resulting capital reshuffling may wipe out or impair

1. Statutes in forty-three jurisdictions grant appraisal rights in the event of one or more types of voluntary corporate readjustment:

Ala. Code ANn. tit. 10, 100 (1940); Aruz. Code ANN. $\S \S 53-306,53-507$ (1939); Ark. Stat. Ann. $\$ 64-703$ (1947); Cal. Corp. Code Ann. $\$ 4300$ et seq. (1947); Colo. Stat. AnN. c. 41, § 57(5) (Cum. Supp. 1949); Conn. Gen. Stat. \$\$ 5139, 5225 (1949); Del. Rev. CODE $\$ 2093$ (1935), as amend. by Laws 1943 c. 125 \$, and Laws 1949 c. 136, § 7; D.C. Code $\$ 29-240$ (1940); Fla. STAT. ANN. $\$ 612.40$ (1943); GA. CodE ANN. $\$ \$ 22-1845$ to 22-1850 (Cum. Supp. 1947); HawaII Rev. Laws $\S 8378-8388$ (1945); IDaHo Code ANN. $\S \S 30-150$, 30-156 (1948); Ill. ANN. Stats. c. 32, $\$ \$ 157.70,157.73$ (Cum. Supp. 1950); Ind. Stat. Ann. § 25-236 (Burns Cum. Repl. 1948), § 25-240 (Burns Cum. Supp. 1949); Iowa Code ANn. $\$ 491.112$ (1949); Kan. Gen. Stat. $\$ 17-3707$ (Cum. Supp. 1947); Ky. Rev. Stat. AnN. $\S \S 271.415,271.490$ (Baldwin Cum. Supp. 1950); La. Rev. Stat. \$ 12:52 (1950); Me. Rev. Stat. c. 49, $\S \S 80-91$ (1944); Mo. ANN. Code GEN. LAws art. 23, $\$ \S 37-39$ (1939) as amend. by Laws 1949 c. 451 ; Mass. Gen. Laws c. 156 , $\S \S 46,46 \mathrm{E}$ (1948); Mich. Stat. Anv. $\S \S 21.44$, 21.54 (Henderson 1935); Minv. Stat. ANv. $§ \S 301.40$, 301.44 (West 1945); Mo. Rev. Stat. ANN. $\delta \S 4997.56,4997.71,4997.73$ (Cum. Supp. 1950); Neb. Rev. Stat. $\$ 21-1,109$ (1943); NEv. CoMr. Laws ANN $\$ 1640$ (Supp. 1941); N.H. Rev. Laws c. 274, $\$ \$ 41,75-79$ (1942); N.J. Stat. ANn. \$§ 14:3-5, 14:12-7 (1937); N.M. Stat. ANn. \$\$ 54-231, 54-906 (1941); N.Y. Stock Corp. Law $\S 21$ (Cum. Supp. 1950); N.C. Gen. Stat. ANN. §55-167 (1943); Ohro Gen. Code AnN. § 8623-72 (1937); OkLa. Stats. ANn. tit. 18, \$§ 1.157-1.161 (Cum. Supp. 1950); Ore. CoMp. Laws ANn. $\$ 77.263$ (1940), $\$ \$ 77.270-77.273$ (Supp. 1943); Pa. StaT. ANn. tit. 15, § 2852-908 (Cum. Supp. 1949); R.I. Gen. Laws c. 116, §56 (1938), as amend. by Laws 1948, c. 1989, §3; S.C. Code ANN. \$\$ 7706, 7759 (1942); TENN. Code ANN. $\S \S 3749,3752,4091$ (Williams 1934); Vt. REv. Stat. $\$ \$ 5821-5823$ (1947); VA. Code ANN. $\S \S 13-47$ to 13-54, 13-85 (1950); WasH. Rev. Stat. ANN. \$3803-41 (Supp. 1940); Wis. Stat. $\S 181.06$ (1949); Wyo. Comp. Stat. Ann. \$ 44-1205 (Cum. Supp. 1949). (Except where specific statutes are quoted, the citation of the statutes will not be repeated in this note).

For good general treatment of appraisal statutes, consult BaLlantine, CoRrorations $\$ \$ 298,299$ (rev. ed. 1946); Stevens, Corporations $\$ 128$ (2d ed. 1949); SEC, Refort on the Study and Investigation of the Work, Activities, Personnel and Functions of Protective and Reorganization Committees, pt. VII, 590-610 (1938) (hereinafter cited as SEC REPORT); Lattin, Remedies of Dissenting Stockholders Under Appraisal Statutes, 45 Harv. L. REv. 233 (1931); Levy, Rights of Dissenting Shareholders to Appraisal and Payment, 15 CORNell L.Q. 420 (1930). See also Notes, 87 A.L.R. 597 (1933), 162 A.L.R. 1237 (1946), 174 A.L.R. 960 (1948).

2. Motuves ror structural readjustment include plans to combine into a larger business unit and a desire to facilitate common stock dividends or financing through elimination of preferred accruals. Common devices to achieve these results are merger or consolidation, sale of substantial corporate assets, and amendment of the corporate charter.

For detailed treatment of readjustments and their effects on minority stockholder interests, consult SEC REPORT 464-589; Dodd, Fair and Equitable Recapitalizations, 55 
rights of some stockholder classes. ${ }^{3}$ To free the controlling majority from minority obstruction, statutes generally abolish the older requirement that stockholders unanimously consent to fundamental corporate change. But to save a dissenter from going along with unwelcome change, compensatory legislation ${ }^{4}$ often compels the corporation to buy out, on demand, shareholders ${ }^{5}$ who promptly object ${ }^{6}$ to specified fundamental actions. ${ }^{7}$ The

HARv. L. REv. 780 (1942); Latty, Fairness-The Focal Point in Preferred Stock Arrearage Elimination, 29 VA. L. REv. 1 (1942); Comments, Statutory Merger and Consolidation of Corporations, 45 YALE L.J. 105, 111-22 (1935); Corporate Recapitalization by Charter Amendment, 46 Y ALE L.J. 985 (1937).

3. Recapitalization by charter amendment may deprive stockholders of voting rights, create stock with preferences over outstanding stock, impair preferred stockholders' rights to prior participation in earnings and assets, and even directly wipe out preferred accruals. Consult Stevens, CoRporations $\$ 127$ (2d ed. 1949); SEC RePort, supra note 1, at 109-97, 480-81, 496-514; Becht, Changes in the Interests of Classes of Stockholders by Corporate Charter Amendments Reducing Capital, and Altering Redemption, Liquidation and Sinking Fund Provisions, 36 CoRNell L.Q. 1 (1950); Dodd, Accrued Dividends in Delaware Corforations-From Vested Right to Mirage, 57 Harv. L. REv. 894 (1944); Comment, 54 YALE L.J. \$40, 842-46 (1945). In McNulty v. W. \& J. Sloane, 184 Misc. 835, 54 N.Y.S.2d 253 (Sup. Ct. 1945) a comprehensive opinion by Shientag, J., weighs the conflicting interests involved in elimination of accruals, and exhaustively cites text and case material on the subject.

Merger or consolidation and sale of corporate assets can prejudice a stockholder class by an unfavorable share exchange basis or a rigged asset sale. See Ballantine, CorporaTIONS $\$ \S 285,295,296$ (rev. ed. 1946); SEC REPORT 294-336.

4. "At common law, unanimous shareholder consent was a prerequisite to fundamental changes in the corporation. This made it possible for an arbitrary minority to establish a nuisance value for its shares by refusal to cooperate. To meet the situation, legislatures authorized the making of changes by majority vote. This, however, opened the door to victimization of the minority. To solve the dilemma, statutes permitting a dissenting minority to recover the appraised value of their shares were widely adopted." Voeller v. Neilston Co., 311 U.S. 531, 535 n. 6 (1941). See also SEC REPoRt 557, 590-91; Levy, supra note 1 , at $420-21$.

For citation to appraisal statutes, see note 1 supra.

5. Appraisal statutes generally do not restrict appraisal rights to voting stock. E.g., California. But see, e.g., statutes of Kansas and Michigan which require a specific negative vote, and see Application of Harwitz, 192 Misc. 91, 93, 80 N.Y.S.2d 570, 573 (Sup. Ct. 1948) (New York appraisal statute not applicable to non-voting stock). Denial of appraisal rights to non-voting stockholders would exclude those who have no voice in the corporate decision and, therefore, are most in need of help.

Courts disagree as to whether a petitioner for appraisal must be a stockholder of record. Compare Application of Bazar, 183 Misc. 736, 50 N.Y.S.2d 521 (Sup. Ct. 1944), affd. mem. sub nom. Matter of Standard Coated Products, 271 App. Div. 1007, 69 N.Y.S.2d 910 (1st Dep't 1947), and In re Rowe, 107 Misc. 549, 176 N.Y. Supp. 753 (Sup. Ct. 1919) (petitioner need not be stockholder of record); with Salt Dome Oil Corp. v. Schenck, 41 A.2d 583 (Del. Sup. Ct. 1945) (must be stockholder of record), criticized in Note, 31 VA. L. REv. 698 (1945). A few statutes like that of California specifically require the dissenter to be a stockholder of record.

6. The dissenter must comply with strict procedural requirements before appraisal of his shares. As a first step, he generally must dissent to the proposed corporate action. Under most statutes, e.g., Connecticut, New Jersey, New York, not voting for the proposed action suffices. A few, however, e.g., Arkansas, Maine, require a specific negative vote. If no negative vote need be cast, the dissenter usually must then file a written objection with 
corporation is required to pay each dissenter an amount equal to his aliquot interest in the business equity. Where the parties cannot come to terms, however, they may resort to statutory appraisal proceedings. Impartial valuation guided by criteria of full or fair value ${ }^{8}$ then sets a binding price, independent of buyers' whim or wayward market, that approximates the stockholder's legitimate expectations of future earnings. ${ }^{9}$

Aloof courts and restrictive legislation often press dissenters to choose between appraisal and acquiescence. Courts, aware of appraisal rights, are

the corporation, often prior to or at the time of the stockholders' meeting voting on the proposed plan. E.g., Connecticut and Delaware. Following expression of dissent, the dissenter typically must make a written demand on the corporation for payment of his shares shortly after the stockholders' meeting or consummation of the proposed action. E.g., Nevada (20 days after filing of merger agreement) and South Carolina (20 days after recording of merger). For discussion of procedure under appraisal statutes, see SEC REPORT 598-604.

7. All of the statutes cited in note 1 supra, except that of the District of Columbia, grant appraisal rights to stockholders dissenting to mergers or consolidations. Twenty-six states allow appraisal in the event of sale of corporate assets, e.g., Illinois, New Jersey, and Ohio. Delaware does not allow appraisal under these circumstances.

Only thirteen statutes grant appraisal rights to dissenters from certain charter amendments, e.g., Maryland, Massachusetts, Ohio. Delaware and New Jersey do not.

The piecemeal scope of appraisal statutes has been severely criticized. Since different readjustment devices can often attain the same result, management can avoid payment of dissenters by simply choosing a device under which the statute does not give appraisal rights. See, Hills, Consolidation of Corporations by Sale of Assets and Distribution of Shares, 19 Calif. L. Rev. 349 (1931); Weiner, Payment of Dissenting Shareholders, 27 CoL. L. Rev. 547,564 (1927). See also cases cited in note 10 infra.

But a few states provide dissenters with a complete arsenal of appraisal rights. In New York, for example, a dissenter can get appraisal of his shares upon sale of assets, alteration of preferential rights by charter amendment, merger or consolidation, and institution of certain employee stock participation plans. N.Y. STock CoRP. LAw $\S \S 20,38,85$, 86,91 (Cum. Supp. 1950).

8. The Court may appoint appraisers, e.g., New YoRK Stock CoRp. LAW \& 21.4 (Cum. Supp. 1950), or will itself appraise the stock, e.g., Tennessee. A few states such as Delaware permit each of the parties to choose one appraiser, who then attempt to agree on a third. If unsuccessful, the court will appoint the third appraiser.

Various standards are applied, e.g., New Jersey (full market value), Ohio (fair cash value), Pennsylvania (fair value), Rhode Island (full and fair value).

For discussion of valuation in appraisal proceedings, see 2 BonBrigat, VALUATION of PROPERTY 826-36 (1937); Robinson, Dissenting Shareholders: Their Right to Dividends and the Valuation of their Shares, 32 CoL. L. REv. 60, 66-78 (1932); Lattin, supra note 1, at 258-70; note, Stock Appraisals: The Dissenting Shareholder and the Concept of Value, 16 BrookL YN L. Rev. 86 (1949); note, 47 HARv. L. REv. 847 (1934); Root v. York Corp., 50 A.2d 52 (Del. Ch. 1946).

9. The dissenter, of course, could sell his shares in the open market. This, however, is cold comfort since a market may not exist, and an existing market is of ten depressed by the news of the very corporate action to which objection is made. BoNBRIGET, op. cit. supra note 8, at 828. See also case analysis in SEC REPORT 346, where an appraised award of $\$ 500,000$ was more than double the market value at the time. Such factors account for decisions like Roessler v. Security Savings \& Loan Co., 147 Ohio St. 480, 72 N.E.2d 259 (1947). The court there held it reversible error to instruct appraisers that "fair cash value" meant a price that willing seller and willing buyer would agree on. 
slow to intervene in intracorporate strife where the claimant shows no unfairness amounting to constructive fraud. ${ }^{10}$ Some appraisal statutes, moreover, expressly bar other adjudication of shareholders' protests. ${ }^{11}$ The growing importance of appraisal statutes as the sole formal tool of compromise ${ }^{12}$ clearly focuses the need for workable proceedings.

Financial burdens incident to appraisal proceedings, however, can thwart the compensatory adjustment intended by the statutes. Unless a shareholder can shift these burdens, appraisal may be a barren right. On the other hand, if his threat of costly proceedings can extort exorbitant settlement, appraisal rights so abused may block or heavily tax desirable corporate change.

Statutes which fail to deal comprehensively with cost problems create a pitfall for the dissenter. Almost half of the forty-three appraisal statutes now in effect do not refer to costs at all, ${ }^{13}$ and others contain cost provisions of generally narrow scope. The latter provide for appraisers' fees in all

10. See Ballantine, Corporations 656, 673, 692 (rev. ed. 1946); Barrett v. Denver Tramway Corp., 53 F. Supp. 198, 201, 205 (D. Del. 1944), aff'd, 146 F.2d 701 (3d Cir. 1944); Porges v. Vadsco Sales Corp., 27 Del. Ch. 127, 32 A.2d 148 (Ch. 1943). The existence of appraisal statutes appears to be a strong factor in courts' disinclination to examine management plans too rigorously. See, e.g., Wessel v. Guantanamo Sugar Co., 134 N.J. Eq. 271, 35 A.2d 215 (Ch. 1944), app. denied, 135 N.J. Eq. 506, 39 A.2d 431 (Ct. Err. \& App. 1944) (recapitalization by charter amendment enjoined at suit of preferred shareholders. The court distinguishes charter amendment with no appraisal rights from mergers calling for appraisal under N.J. statute); Porges v. Vadsco Sales Corp., supra; McNulty v. W. \& J. Sloane, 184 Misc. 835, 844, 54 N.Y.S.2d 253, 262 (Sup. Ct. 1945). And compare Keller v. Wilson \& Co., 21 Del. Ch. 391, 190 Atl. 115 (Sup. Ct. 1936), with Havender v. Federal United Corp., 24 Del.Ch. 318, 11 A.2d 331 (Sup. Ct. 1940). Keller, which "astonished the corporate world," held that preferred accruals could not be wiped out by charter amendment. Havender, which "astounded it," held that preferred accruals could be eliminated by merger with an inactive subsidiary. See Hottenstein v. York Ice Machinery Corp., 136 F.2d 944, 950 (3d Cir. 1943). DEL. Rev. Cone $\$ 2093$ (1935) grants appraisal rights to dissenters to mergers, but not to charter amendments. The Delaware cases are analyzed by Dodd, supra note 3 , at 895-99.

11. E.g., statutes of California and Pennsylvania, applied in Beechwood Securities Corp. v. Associated Oil Co., 104 F.2d 537 (9th Cir. 1939) and Hubbard v. Jones \& Laughlin Steel Corp., 42 F. Supp. 432 (W.D. Pa. 1941).

12. This development is approved by Ballantine \& Sterling, Upselting Mergers and Consolidations: Alternative Remedies of Dissenting Shareholders in California, 27 CALIF. I. REv. 641, 650-62 (1939). Sharply critical views are taken by SteveNs, Corporations 591-96 (2d ed. 1949) and Lattin, A Reappraisal of Appraisal Statutes, 38 MICH. L. REv. $1165,1168-73(1940)$, who considers exclusive appraisal statutes a "sacrifice of honesty to practicality."

Recent decisions, however, take the former position. Adams v. United States Distributing Corp., 184 Va. 134, 34 S.E.2d 244 (1945); Blumner v. Federated Dept. Stores, Inc., 99 N.Y.S.2d 691 (Sup. Ct. 1950) ("The dissenter is confined to appraisal; this is the philosophy of the statute."); see Johnson v. Spartansburg County Fair Ass'n, 210 S.C. 56, 70, 41 S.E.2d 599, 605 (1947).

13. E.g., Alabama, Arizona, Colorado, Connecticut (merger), Georgia, Idaho, Kansas, Massachusetts, Michigan, New Jersey. 
cases, counsel's fees rarely, and experts' fees in but one instance. ${ }^{14}$ Since courts point to legislative omissions as grounds for declining cost reimbursement, these direct cost burdens have commonly rested on the dissenter. ${ }^{15}$ Some statutes, moreover, explicitly bar cost coverage of counsel or experts. ${ }^{16}$ As a result, the average investor faced with outlays disproportionate to the value of his holdings is barred from asserting his rights under the statute. ${ }^{17}$

Moreover, statutes often cut off the dissenter from all his rights as a stockholder except payment of the appraised share value. ${ }^{18}$ Only a few require continuation of dividends or payment of interest on his investment

14. Appraisers' fees are specifically authorized by thirteen states, e.g., Delaware, Ohio, Pennsylvania.

Counsels' fees are authorized by Arkansas, Florida, Oregon, South Carolina, Tennessee.

Only New York by virtue of the 1950 revision makes provision for experts' fees.

15. Appraisers' fees: In re Janssen Dairy Corp., 2 N.J. Super. 580, 64 A.2d 652 (1949). Confronted with the silence of the New Jersey appraisal statute, the court inferred an obligation of the parties to share equally the burden of appraisers' fees. Where payment of appraisers by the corporation was intended, says the court, statutes have been more explicit. Cf. Schultz v. Mountain Telephone Co., 364 Pa. 266, 72 A.2d 287 (1950) (under analogous statute, order taxing appraisers' fees against corporation reversed because of statutory silence on costs).

Counsel fees: In re Janssen Dairy Corp., supra; of. Schultz v. Mountain Telephone Co., supra.

Experts' fees: Application of Behrens, 61 N.Y.S.2d 179 (Sup. Ct. 1946) aff'd mem. sub nom. Matter of Standard Coated Products, 271 App. Div. 1007, 69 N.Y.S.2d 910 (1st Dep't 1947). Contra: Ashton v. Pittsburgh Consolidated Coal Co., 69 Pa. D. \& C. 277 (Com. Pl., Allegheny County 1949) (applying "equitable doctrines," court taxes experts' costs against the corporation, although no specific statutory authorization).

16. Delaware, Kentucky, Washington.

17. The appraisers' fees in In re Janssen Dairy Corp., supra note 15, amounted to $\$ 6000$. In Schultz v. Mountain Telephone Co., supra note 15, appraisers' and counsel fees totaled $\$ 3000$. Experts' costs were over $\$ 9500$ in Ashton v. Pittsburgh Consolidated Coal Co., supra note 15. In Matter of Said, 97 N.Y. L.J. 3190, col. 1 (Sup. Ct. June 24, 1937), an extremely complex valuation resulted in appraisers' fees of $\$ 100,000$. Assets amounting to over $\$ 11$ million of a parent with sixteen subsidiaries in seven countries were valuated.

Litigation in a distant forum imposes another cost roadblock. In Meade v. Pacific Gamble Robinson Co., 21 Wash.2d 866, 153 P.2d 686 (1944), a Washington stockholder in a Delaware Corporation having its main office and place of business in Washington was barred from appraisal in Washington. A discretionary refusal to exercise jurisdiction also tripped the dissenter in Weiss v. Routh, 149 F.2d 193 (2d Cir. 1945), where New York law was applied to dismiss the suit of a dissenting stockholder of a Virginia corporation.

Ballantine, Corporations 702 (rev. ed. 1946) concludes that the costs of appraisal are prohibitive as far as the ordinary investor is concerned, because only a few statutes make adequate provision for counsel fees and other expenses of the petitioner.

18. "Any stockholder demanding payment for his stock . . . shall cease to have any other rights of a stockholder of the corporation with respect to such stock, except the right to receive payment for the value thereof. . . N.Y. Stock CoRp. Law § 21.6 (Cum. Supp. 1950).

Similar provisions appear in the statutes of Arkansas, Florida, Georgia, Kentucky, Michigan, Nevada, North Carolina, Ohio, Tennessee. 
from valuation reference date until final award. ${ }^{19}$ Denial of a dissenter's claims to dividends or interest ${ }^{20}$ sterilizes his capital during proceedings which may drag on for years. ${ }^{21}$ This indirect cost burden may prove more onerous than immediate sell-out at a loss. Consequently, even a large shareholder who can absorb direct costs may find appraisal worthless.

On the other hand, unscrupulous dissenters can exploit some statutory cost apportionment schemes. A few states unqualifiedly assess all costs of the proceeding against the corporation. ${ }^{22}$ Motives for dissent are beyond judicial scrutiny, ${ }^{23}$ and neither minimal share interest ${ }^{24}$ nor intent to harass

19. Continued dividends must be paid under the statutes of California, Ohio and Okla-

Interest is authorized by the statutes of Delaware, Iowa, Maryland, New York, Washington and Wisconsin.

The valuation reference date, i.e., the date as of which the appraisers fix the value of a dissenter's shares, is typically the day before the stockholders' vote on the action to which dissent is taken, e.g., Michigan, New York and Pennsylvania.

20. Dividends were denied in Ames v. Godchaux Sugars, Inc., N.Y. Sup. Ct., Jan. 15, 1930, aff. without opinion, 228 App. Div. 801, 239 N.Y. Supp. 917 (1st Dep't 1930). The unreported Supreme Court opinion is partially reprinted in Robinson, supra note 8 , at 63-64. Statutory amendment, however, has since solved the problem in New York. See note 30 infra.

For cases denying interest see, e.g., In re Janssen Dairy Corp., 2 N.J. Super. 580, 64 A.2d 652 (1949); Meade v. Pacific Gamble Robinson Co., 51 A.2d 313 (Del. Ch. 1947), aff'd, 58 A.2d 415 (Del. Sup. Ct. 1948). But cf. Skipwith v. Federal Water and Gas Corp., 185 Misc. 248, 56 N.Y.S.2d 804 (Sup. Ct. 1945). In the New Jersey case the silence of the statute was construed to negative inferentially the claim to interest. The Court thought, however, that the claim had "much to be said for it," and considered the problem to "bespeak legislative aid." The Delaware Vice-Chancellor conceded that he would allow interest if he were free to do so, but found the Delaware statute's silence an insurmountable barrier. After sharply criticising the Skipwith case, supra, where a New York court construing the Delaware statute had allowed interest, for its notions of "simple justice" in disregard of statutory language, he requested enlightenment from the legislature. Enlightenment came to Delaware by Del. Laws 1949 c. $136, \S 7$; New Jersey appears still in the dark. See also, Note, 21 VA. L. REv. 825 (1935).

21. Horner, Statutory Provisions for Valuation and Purchase of Shares of Dissenting Shareholders, 1 SoutHWESTERN L.J. 207, 215-19 (1947). In the course of a general attack on appraisal statutes the author discusses several cases consuming years of fruitless appraisal litigation.

22. Connecticut (sale of assets), Nebraska, Oregon, Rhode Island, South Carolina, Virginia.

23. Marcus v. R. H. Macy \& Co., 297 N.Y. 38, 74 N.E. 2d 228 (1947); Matter of Nulle, 194 Misc. 622, 87 N.Y.S.2d 565 (Sup. Ct. 1949). Where, however, a dissenter has acquired his shares after notice of the proposed corporate action, appraisal may be denied. $C f$. Graves v. Pittsburgh Consolidation Coal Co., $355 \mathrm{~Pa} .224,49$ A.2d 344 (1946) (dissenter before notice of merger owned 200 shares; sold 100 of these but acquired 100 others after merger approved; held entitled to appraisal of only 100 shares); Application of Stern, 82 N.Y.S.2d 78 (Sup. Ct. 1948) (under analogous statute, dissenter who purchased shares after merger plan publicized, held not a bona fide stockholder entitled to appraisal); see Matter of Leventall, 241 App. Div. 277, 283, 271 N.Y. Supp. 493, 500 (1st Dep't 1934).

24. Marcus v. R. H. Macy, supra note 23; Borea v. Locust Courts Apartments, Inc., 234 App. Div. 450, 255 N.Y. Supp. 215 (2d Dep't 1932) (right to appraisal upheld although 
blocks access to appraisal. ${ }^{25}$ This permits dissenters to wield the threat of an intensive probe of corporate records and detailed inventory of assets at corporation expense. Accordingly, extortioners may be able to blackmail the corporation into exorbitant settlement to avoid unwelcome and costly appraisal proceedings.

Finally, even when statutes purport to distribute costs fairly, mechanical allocation tests often foil the result. Razor's edge criteria of who pays must arbitrarily strike one or the other party to the proceeding. Typically, the corporation has to bear all costs if the appraised share value exceeds its settlement offer. ${ }^{26}$ If not, the burden falls on the dissenter, is divided equally,

court doubts whether shares are of any substantial value); Costello v. Bethlehem Steel Co., 49 Pa. D. \& C. 126 (Com. Pl. Northampton County 1943) (right to appraisal upheld though the sole appraisal claimant owns only 10 of 169,356 outstanding shares).

25. See Note, Extortionate Corporate Litigation: The Strike Suit, 34 CoL. L. REv. 1308 (1934). The author lists five indicia of "extortionate" motive: a) claimant's reputation as a striker, b) recent acquisition of shares, c) peculiar circumstances surrounding acquisition, d) possession of small share interest, e) claimant's lack of support from others similarly situated. Id. at $1310 \mathrm{n}$. 8. Only criterion b) appears to be a factor barring access to appraisal proceedings.

An interesting case study is presented by the Marcus v. R. H. Macy \& Co. litigation in New York at a time when the appraisal statute taxed all costs against the corporation. Marcus had been the owner of 50 shares of Macy common since 1943. In 1946 the corporation, by the vote of $1,332,408$ shares, adopted a resolution to amend its charter to extend voting rights to preferred stock. Marcus was the sole dissenter to this action which reduced her proportional voting control in the corporation from 30/1,000,000 to $27 / 1,000,000$. On the date of the corporate vote, $i . e$., the valuation reference date, Macy common sold on the New York Stock Exchange between a low of $431 / 8$ and a high of $433 / 4$, giving Marcus' shares a market value of about $\$ 2,175$. Nevertheless, she demanded $\$ 20,000$. Petition for appraisal was denied by the New York Supreme Court in an unreported opinion, aff'd mem., Matter of Marcus, 270 App. Div. 934, 62 N.Y.S.2d 824 (1st Dep't 1946). On appeal, despite Macy's argument that Marcus was engaging in a strike suit and that an adverse determination would force it to suffer the needless cost of an appraisal proceeding or pay "the raider's price," the Court of Appeals reversed. Marcus v. R. H. Macy \& Co., 297 N.Y. 38, 74 N.E.2d 228 (1947). Armed with this decision, Marcus served Macy with a subpoena duces tecum calling for the production of all the books, records, and working papers of the company and each of its subsidiaries, operating department stores in five states, relating to their financial condition, physical inventory, and fixed assets as of the valuation reference date. In addition, she secured an order calling on the appraisers to select a certified public accountant to prepare an audit, as part of the expense of the appraisal to be paid by Macy. Macy's motion to vacate was denied, but the scope of the subpoena duces tecum was narrowed. Matter of Marcus, 191 Misc. 808, 77 N.Y.S.2d 529 (Sup. Ct. 1948). On appeal, Peck, P. J., in a caustic opinion reversed, noting that"Marcus' tactics in the appraisal proceeding appeared "of a piece with her demand for payment of tenfold the open market value of her stock." The court held that an adequate appraisal could be had on the basis of readily available information, without resort to the "kind of inquiry petitioner would make." Matter of Marcus, 273 App. Div. 725, 79 N.Y.S.2d 76, rearg. and appeal den'd., 274 App. Div. 822, 81 N.Y.S.2d 199 (1st Dep't 1948).

For similar tactics see Manning v. Brandon Corporation, 163 S.C. 178, 161 S.E. 405 (1931), criticized in Horner, supra note 21, at 218.

26. Arkansas, California, District of Columbia, Florida, Louisiana, Nevada. 
or is allocated "as equitable." ${ }^{27}$ Such failure to allow a margin for honest error or differing judgment disregards the complexities of property valuation, puts minor variation on a par with gross discrepancy, and glosses over unfair practices by either side.

The 1950 revision of the New York appraisal statute ${ }^{28}$ represents the first legislative attempt to deal comprehensively with the problems of cost apportionment. Under the statute basic costs of the proceeding, which include fees and expenses of appraisers but not of parties' counsel or experts, generally are assessed against the corporation. ${ }^{29}$ The dissenter's shares accumulate interest until final judicial award. ${ }^{30}$ If the award materially exceeds the corporation's settlement offer, or no offer was made, the dissenter may also recover reasonable expenditures for necessary experts. ${ }^{31}$ But if the court finds that the dissenter in bad faith has rejected a settlement offer, he may be taxed for any part of the proceeding's basic costs and may recover no interest on his investment. ${ }^{32}$

New York's cost provisions both aid the dissenter and protect the corporation. To a bona fide claimant, the revised statute affords broad relief. Appraisers' fees are taxed against the corporation. In addition the dissenter

27. Dissenter: District of Columbia, Louisiana. Divided equally: Arkansas, Florida. Allocated "as equitable": California, Nevada.

28. New York Stock Corp. Law § 21 (Cum. Supp. 1950), enacted by New York Laws 1950 , c. $647, \S 1$, effective July $1,1950$.

29. "The costs and expenses of the proceeding shall be determined by the court and shall be assessed against the corporation; provided, that all or any part of such costs and expenses may be apportioned and assessed as the court may deem equitable against any or all of the objecting stockholder parties to the proceeding to whom the corporation shall have made an offer to pay for the stock if, taking into consideration the value of the stock as determined in the proceeding, the financial statements furnished to such stockholders, and such other circumstances as the court may deem relevant, the court shall find that the action of such stockholders in failing to accept such offer was arbitrary and vexatious or not in good faith. Such expenses shall include reasonable compensation to and the reasonable expenses of the appraiser but shall exclude the fees and expenses of counsel and of experts retained by any party; provided, that if the value of the stock as determined in the proceeding shall materially exceed whatever amount the corporation may have offered to pay therefor, or if no offer shall have been made, the court, in its discretion, may award to any stockholder party to the proceeding such sum as the court may determine to be reasonable compensation to any expert or experts retained by such stockholder in the proceeding if the court shall find the retaining of such expert or experts to have been reasonably necessary." NEW YORK Stock CORP. LAW $\$ 21.5$ (Cum. Supp. 1950).

30. "Any judgment for the value of stock . . . shall include interest from the date of the stockholders' vote on the action to which objection was made; provided, that if, taking into consideration the price which the corporation may have offered to pay for such stock, the financial statements furnished to the stockholder, and such other circumstances as the court may deem relevant, the court shall find that the action of the stockholder in failing to accept such offer was arbitrary and vexatious or not in good faith, no interest shall be allowed." NEw York Stock Corp. LAw \& 21.4 (Cum. Supp. 1950).

31. See note 29 , supra.

32. See notes 29 and 30 supra. The statutory standard for cost imposition and denial of interest is whether the dissenter's refusal of an offer was "arbitrary and vexatious or not in good faith." 
can recover experts' fees whenever a court finds the corporation's bargaining has not measured up to the statutory standards. New York thus clearly recognizes that the economic and accounting problems of share valuation ${ }^{33 .}$ may call for costly expert presentation of claims and that a dissenter often cannot afford this cost. Though the dissenter must still pay his counsel, ${ }^{34}$ formidable cost roadblocks to appraisal are now cleared. But on the otherhand, flexible cost imposition shields the corporation from extortionate claims by dissenters. Since the court has discretionary powers to assess. appraisers' fees against rapacious dissenters and to withhold interest on their shares, vexatious suits against the corporation should be effectively. curbed.

But more important are the cost incentives that impel parties to come to. fair terms without recourse to formal appraisal proceedings. If it is to. escape cost liability later, the corporation initially must offer to purchase a dissenter's shares ${ }^{35}$ at a price not materially below their value. Betteraccess to data and expertise essential to investment valuation ensures that the corporation's judgment will be more accurate than a dissenter's often uninformed guess. Failure to make a reasonable offer may lead to imposition of the full cost burden of a subsequent appraisal proceeding on the corporation. ${ }^{36}$ The dissenter, on the other hand, cannot with impunity disregard. reasonable settlement offers. If he arbitrarily rejects them and vexatiouslyinsists on appraisal, the financial burdens of the proceeding may fall on him. ${ }^{37}$ Since flexible imposition of costs makes unfair dealing risky for either side, looming cost burdens set the outer limits of settlement terms. And as mutual aversion to costly proceedings bridges minor gaps in the negotiations, settlements probably will result in most cases. ${ }^{38}$

Fair extra-judicial settlements that entirely eliminate the costs of formal

33. For emphasis of the economic and accounting aspects of appraisals see the conclusion of Lattin, Remedies of Dissenting Stockholders under Appraisal Statutes, 45 HARV. L.. REv. 233, 270 (1931).

34. This rigor is mitigated by NEw YORK CIVIL PRACTICE ACT $\$ \S 1486,1492$ (GilbertBliss 1949), held applicable to appraisal proceedings by Matter of Baker, 284 N.Y. 1, 29 N.E.2d 241 (1940). In that case, where the appraised value exceeded the amount for which the corporation argued, the court upheld an award of motion costs and trial fee to dissenters, the "prevailing" parties in a "special proceeding."

35. "[T]he corporation, within ten days after the last day on which a demand for payment might have been made, shall mail . . . to such objecting stockholder . . . a written offer to pay for such stock in cash at a price deemed by the corporation to be the valuethereof. . . ." NEw YoRk Stock CoRP. Law § 21.1 (Cum. Supp. 1950).

36. This will include appraisers' and experts' fees, and interest on the dissenter's shares. See notes 29 and 30 supra.

37. In that event, the dissenter may be taxed any part of appraisers' fees and will be denied interest on his investment. See notes 29 and 30 supra.

38. The January 1950 Memorandum of the Committee on Corporation Law of the NewYork State Bar Association Relative to Proposed Revision of Section 21 of the Slock Corporation Law concludes that the statutory revision's effect will be to "dispense with the necessity of" an appraisal in many instances." 